\title{
Effect of diazotrophic bacteria and thiamine on growth and regrowth of millet
}

Eduardo Pradi Vendruscolo ${ }^{1}$, Paulo Ricardo Oliveira ${ }^{1}$, Jefferson Guimarães Silva ${ }^{1}$, Joana Pradi Vendruscolo ${ }^{2}$, Luiz Fernandes Cardoso Campos ${ }^{3}$, Rodrigo Andrade Leitão ${ }^{1}$, Alexsander Seleguini ${ }^{4}$

${ }^{1}$ Universidade Federal de Goiás, Escola de Agronomia, Campus Samanbaia, GO. ${ }^{2}$ Universidade Federal de Santa Catarina - UFSC, Centro de Ciências Agrárias, Florianópolis, SC. ${ }^{3}$ Universidade Estadual de Goiás, Campus de São Luís de Montes Belos, GO. ${ }^{4}$ Universidade Federal do Triângulo Mineiro, Campus Iturama, MG

\begin{abstract}
New technologies are constantly being launched, however studies that point to the effects of their joint application are lacking. The objective of this study was to evaluate the effect of the isolated and joint use of Azospirillum brasilense inoculation and the application of thiamine, on seed or leaf, on the development of millet in two cycles. A randomized complete block design was used in five replicates. The treatments were composed of the isolated or combined inoculation with Azospirillum brasilense and the application of thiamine, on seed $\left(10 \mathrm{ml} \mathrm{kg}^{-1}\right)$ or leaf spray $(10 \mathrm{ppm})$. The relative levels of chlorophyll $\mathrm{a}, \mathrm{b}$ and total, plant height, number of shoots, fresh and dry mass production and dry matter index of plants were evaluated. In the first cycle, treatments were only effective for the relative chlorophyll contents, and in general, the treatment with isolated inoculation of $A$. brasilense stood out, differing significantly from the treatment with thiamin applied on seed. In the second cycle, there was significant effect of the treatments on the variables of plant height and number of shoots, in which a maximum height of $165 \mathrm{~cm}$ and production of 140 shoots $\mathrm{m}^{-2}$ with application of thiamin on seed and with the use of $A$. brasilense and thiamine applied on the leaf, respectively. Thus, it was concluded that inoculation with $A$. brasilense increases the relative chlorophyll content in millet during the first cycle. The joint use of inoculation with $A$. brasilense and the application of thiamine can be used as a strategy to increase the number of shoots.
\end{abstract}

Keywords: Pennisetum glaucum L.; biostimulant; vitamin B1; biological nitrogen fixation.

\section{Efeito de bactérias diazotróficas e tiamina sobre crescimento e rebrota de milheto}

\section{Resumo}

Novas tecnologias estão constantemente sendo lançadas, no entanto faltam estudos que apontem para os efeitos da aplicação conjunta destas. O presente estudo teve como objetivo avaliar o efeito da utilização isolada e conjunta da inoculação com Azospirillum brasilense e aplicação de tiamina, via semente ou foliar, sobre o desenvolvimento do milheto, em dois ciclos. Foi utilizado o delineamento de blocos ao acaso, em cinco repetições. Os tratamentos foram compostos pela utilização isolada ou conjunta da inoculação com Azospirillum brasilense e aplicação de tiamina, via semente $\left(10 \mathrm{ml} \mathrm{kg}^{-1}\right)$ ou spray foliar (10 ppm). Foram avaliados os teores relativos de clorofila $a, b$ e total, altura de planta, número de brotações, produção de massa fresca e seca e o índice de matéria seca das plantas. No primeiro ciclo houve resposta aos tratamentos apenas para os teores relativos de clorofila, sendo que, de modo geral, o tratamento com inoculação isolada de $A$. brasilense sobressaiu-se, diferindo significativamente do tratamento com aplicação de tiamina via semente. No segundo ciclo houve efeito dos tratamentos sobre as variáveis de altura de planta e número de brotações, nos quais se observou altura máxima de $165 \mathrm{~cm}$ e produção de 140 brotações por $\mathrm{m}^{2}$ com aplicação de tiamina via semente e com a utilização conjunta do $A$. brasilense e da tiamina aplicada via spray foliar, respectivamente. Assim, concluiu-se que a inoculação com $A$. brasilense aumenta o teor relativo de clorofila no milheto durante o primeiro ciclo. $O$ uso conjunto de inoculação com A. brasilense e a aplicação de tiamina podem ser utilizados como estratégia para aumento do número brotações.

Palavras-chave: Pennisetum glaucum L.; bioestimulante; vitamina B1; fixação biológica de nitrogênio. 


\section{Introduction}

About one-third of the world's arable land is occupied for animal feed, an effect of increasing demand for products of this origin (FAO, 2017a). China emerges as the largest beef producer, followed by Brazil, which holds about $13.0 \%$ of the 300 million tons produced worldwide in 2015 (FAO, 2017b). In that same year, the country had a herd of 172 million animals (IBGE, 2017), which is mostly pastured, reducing production costs and increasing market competitiveness (DIAS-FILHO, 2016). Thus, the quality of pasture has great national importance and technologies must be sought in order to provide greater sustainability of the productive system.

Millet (Pennisetum glaucum L.) is a grass used as a forage species with high nutritional value (GÖRGEN et al., 2016) and characteristics of erect growth, high size, uniform development and good tillering, even when submitted to stress conditions due to lack of water, which favors its use in tropical regions (KISSMANN, 1997). In Brazil, the species started to arouse the interest of producers, becoming a crop of commercial value, such as forage, mainly after the introduction of hybrids with high productive potential (DAN et al., 2010). However, their cultivation still demands information to improve the production system.

Among the existing technologies, it is the ability of some bacteria to perform atmospheric nitrogen fixation, thanks to the functional nitrogenase enzyme, which converts the nitrogen present in the atmosphere $\left(\mathrm{N}_{2}\right)$ into forms that can be used to build plant tissues (HUNGRIA, 2011; BATTISTUS et al., 2014). The process is much explored in the cultivation of several plant species belonging to the Fabaceae family, such as soybeans and common bean, using bacteria of the genus Rhizobium (PEREIRA et al., 2013, ROHRIG et al., 2016). In grasses, studies involving biological nitrogen fixation are more recent and involve bacteria of the genus Azospirillum, which can promote vegetative development, improving production in quality and quantity (HUNGRIA, 2011; LONGHINI et al., 2016).

The application of bacteria of the genus Azospirillum in species used as forage has presented promising results. In a study with inoculation of different strains of Azospirillum in Brachiaria grass, Guimarães et al. (2011) observed that some of the bacteria positively influenced the development and the relative chlorophyll index. Also Vogel et al. (2014) carried out a survey on the inoculation of forage species with $A$. brasilense, verified the potential use of the bacteria as a promoter of vegetative development and forage quality and can be used as an alternative to partially replace the nitrogen fertilization.

In addition to the inoculation with diazotrophic bacteria, new techniques are sought that help in the efficiency of the productive systems. In this sense, the introduction of vitamins has been demonstrating the potential to increase the performance of species of economic interest, especially vitamins belonging to the $B$ complex (HENDAWY; EL-DIN, 2010; MOHSEN et al., 2013; SOLTANI et al., 2014).

Thiamine, or vitamin B1, has a complex action on plant metabolism, improving the absorption of water and nutrients, increasing the nutritional and energy reserves and contributing to the activation of defense mechanisms (AHN et al., 2005; BOUBAKRI et al., 2012, KAYA et al., 2014). These effects culminate in gains in the vegetative and reproductive development of different plant species (OERTLI, 1987; HENDAWY; EL-DIN, 2010; SOLTANI et al., 2014). In this sense, increases in the vegetative organs of the mustard crop were observed (VENDRUSCOLO et al., 2017), as well as yield increases for the sweet corn crop (VENDRUSCOLO et al., 2018).

The benefits related to the inoculation with diazotrophic bacteria and the use of thiamine can be of great value to the increase of pasture production for animal feed. However, studies should be conducted in order to define methodologies for the use of these products in an effective way, as no work on this subject is found.

The objective of this study was to evaluate the effect of the isolated and joint use of the inoculation with Azospirillum brasilense and the application of thiamine, on seed or leaf, on the development of millet in two cycles.

\section{Material and Methods}

The study was conducted in a protected arc-style environment, covered with clear plastic and containing anti aphid screen on the sides, located in the city of Goiânia, Goiás, Brazil. The municipality is located in the central region of the State, $16^{\circ} 40$ 'S, $49^{\circ} 15^{\prime} \mathrm{W}$ and altitude of $750 \mathrm{~m}$. 
It presents as average climatic indicators: annual precipitation of $1575 \mathrm{~mm}$ and average monthly temperature of $22.9^{\circ} \mathrm{C}$, with predominance of $\mathrm{Aw}$ climate, characterized by tropical climate with rainy season from October to April and a period with precipitations below $100 \mathrm{~mm}$ monthly between May to September (CARDOSO et al., 2015).

The installation of the experiment was performed on November 30, 2016. Ten millet seeds were arranged in 18-liter pots filled with soil classified as a latossolo vermelho (SANTOS et al., 2013), present in the experimental area. After 12 days of sowing the thinning of the plants was carried out, keeping only two per pot. The soil used was submitted to laboratory analysis, presenting the following characteristics: $\mathrm{Ca}^{2+}=2,0$ $\mathrm{cmol}_{\mathrm{C}} \mathrm{dm}^{-3}, \mathrm{Mg}^{2+}=0,81 \mathrm{cmol}_{\mathrm{c}} \mathrm{dm}^{-3}, \mathrm{~K}^{+}=131,0 \mathrm{mg}$ $\mathrm{dm}^{-3}, \mathrm{P}$ (Mehlich I) $=3,5 \mathrm{mg} \mathrm{dm}^{-3}$, Organic matter $=7,0 \mathrm{~g} \mathrm{dm}^{-3}, \mathrm{Al}^{3+}=0,0 \mathrm{cmol}_{\mathrm{c}} \mathrm{dm}^{-3}, \mathrm{H}+\mathrm{Al}=2,5 \mathrm{cmol}_{\mathrm{c}}$ $\mathrm{dm}^{-3}$ and $\mathrm{pH}\left(\mathrm{CaCl}_{2}\right)=4,6, \mathrm{CTC}=5,6 \mathrm{cmol}_{\mathrm{c}} \mathrm{dm}^{-3}$, $\mathrm{V} \%=55,7 \%$ (DONAGEMMA et al., 2011). The soil granulometric analysis showed $48 \mathrm{~g} \mathrm{~kg}^{-1}$ of clay in the layer 0-0,2m (SILVA, 2009).

The experimental design was a randomized block design for six treatments, in five replications. For the composition of the treatments the following combinations were used: T1 - Control, without application; T2 Inoculation with Azospirillum brasilense $\left(10 \mathrm{ml} \mathrm{kg}{ }^{-}\right.$ $\left.{ }^{1}\right)$ (Masterfix Gramíneas, Stoller, Campinas, São Paulo, Brazil); T3 - Thiamine application on seed (10 $\left.\mathrm{mg} \mathrm{kg}^{-1}\right)$; T4 - Inoculation with A. brasilense $\left(10 \mathrm{ml} \mathrm{kg}^{-1}\right)$ and application of thiamine on seed $\left(10 \mathrm{mg} \mathrm{kg}^{-1}\right)$; T5 - Foliar Application of thiamine (10 ppm); T6 - Inoculation with A. brasilense (10 $\mathrm{ml} \mathrm{kg}$ ) and foliar application of thiamine (10 $\mathrm{ppm})$. The doses were based in previous studies (OERTLI, 1987).

The inoculation with $A$. brasilense and the application of thiamine via seeds were carried out with a graduated pipette directly on the seeds, followed by stirring in polythene bags for one minute for homogeneous distribution of the products. Leaf application of thiamine was carried out 13 days after planting, using a hand sprayer with a flow rate of $10 \mathrm{ml} \mathrm{s}^{-1}$, for $10 \mathrm{~s}$.

The data were collected after two productive cycles, when the plants were in preflowering phase. The first cut was performed at 58 days after sowing, while the second cut was performed at 80 days after sowing, 22 days after the first cut. The plant height was measured with a graduated tape, the relative chlorophyll $a, b$ and total content were obtained by the chlorophyll meter reading $\left(\right.$ Falker $\left.^{\circledR}\right)$ and the number of shoots was counted before cutting the plants. The plants were then cut to obtain the fresh and dry mass, by drying in forced air ventilation oven at $65{ }^{\circ} \mathrm{C}$ until obtaining a constant mass. The dry mass index was obtained by the ratio between the dry mass and the fresh mass of the plants. All the parameter were evaluated for both cut, first and second.

The data were submitted to analysis of variance and the means were compared by Tukey test to the probability of $5 \%$ on Sisvar statistical software (FERREIRA, 2014).

\section{Results and Discussion}

It was observed that the treatments applied differentially affected the behavior of millet plants during the first and second cycle. In the first cycle, only the relative levels of chlorophyll a, b and total were affected, while in the second cycle the characteristics of plant height and number of shoots were affected (Table 1). 
Table 1. Relative chlorophyll content and developmental characteristics of millet plants submitted to inoculation with $A$. brasilense and treatment with thiamine.

\begin{tabular}{|c|c|c|c|c|c|c|c|c|}
\hline \multirow{3}{*}{ Treatments } & \multicolumn{8}{|c|}{ 1st Harvest } \\
\hline & CA & $\mathrm{CB}$ & CT & HP & SN & FM & DM & DMI \\
\hline & (SPAD) & (SPAD) & (SPAD) & $(\mathrm{cm})$ & $\left(m^{2}\right)$ & $\left(\mathrm{kg} \mathrm{m}^{2}\right)$ & $\left(\mathrm{kg} \mathrm{m}^{2}\right)$ & (\%) \\
\hline Control & $35.73 a b^{*}$ & 12.45ab & $48.18 a b$ & $94.86 a$ & $45.00 a$ & $6.39 a$ & $0.85 a$ & $13.20 \mathrm{a}$ \\
\hline A. brasilense & $40.42 a$ & $17.77 a$ & $58.18 a$ & $95.15 a$ & $41.00 a$ & $6.06 a$ & $0.77 a$ & $12.60 a$ \\
\hline Thiamine (seed) & $33.81 b$ & $11.65 \mathrm{~b}$ & $45.46 \mathrm{~b}$ & 113.95a & $45.00 a$ & $5.33 a$ & $0.74 a$ & $13.80 a$ \\
\hline $\begin{array}{l}\text { A. brasilense + Thiamine } \\
\text { (seed) }\end{array}$ & $39.14 a$ & 16.73ab & $55.86 a b$ & 131.02a & $45.00 \mathrm{a}$ & $6.04 a$ & $0.85 a$ & $14.00 \mathrm{a}$ \\
\hline Thiamine (spray) & $36.18 a b$ & 13.70ab & 49.88ab & 119.94a & $42.00 a$ & $6.29 a$ & $0.79 a$ & $13.00 a$ \\
\hline $\begin{array}{l}\text { A. brasilense + Thiamine } \\
\text { (spray) }\end{array}$ & $36.75 a b$ & 14.66ab & 51.41ab & 114.77a & $41.00 \mathrm{a}$ & $5.64 a$ & $0.77 a$ & $13.60 \mathrm{a}$ \\
\hline MSD & 5.22 & 6.02 & 11.08 & 98.25 & 13.40 & 2.83 & 0.09 & 2.40 \\
\hline \multirow[t]{2}{*}{$\mathrm{CV} \%$} & 7.21 & 21.22 & 11.00 & 45.00 & 15.83 & 24.26 & 25.53 & 9.16 \\
\hline & \multicolumn{8}{|c|}{ 2nd Harvest } \\
\hline \multirow[t]{2}{*}{ Treatments } & CA & CB & CT & HP & SN & FM & DM & DMI \\
\hline & (SPAD) & (SPAD) & (SPAD) & $(\mathrm{cm})$ & $\left(m^{2}\right)$ & $\left(\mathrm{kg} \mathrm{m}^{2}\right)$ & $\left(\mathrm{kg} \mathrm{m}^{2}\right)$ & (\%) \\
\hline Control & $39.29 a$ & $15.01 \mathrm{a}$ & $54.30 a$ & $142.80 \mathrm{abc}$ & $92.70 \mathrm{~b}$ & $7.44 a$ & $1.07 a$ & $14.29 a$ \\
\hline A. brasilense & 40.10a & $15.26 a$ & $55.36 a$ & $131.03 b c$ & $91.30 \mathrm{~b}$ & $6.89 a$ & $0.95 a$ & $13.78 a$ \\
\hline Thiamine (seed) & 41.73a & $16.85 a$ & $58.58 a$ & $165.00 a$ & $90.00 \mathrm{~b}$ & $6.52 a$ & $1.04 a$ & $16.07 a$ \\
\hline $\begin{array}{l}\text { A. brasilense + Thiamine } \\
\text { (seed) }\end{array}$ & $40.23 a$ & $15.72 \mathrm{a}$ & $55.95 a$ & $139.83 a b c$ & 103.30ab & $7.55 a$ & $1.13 a$ & $14.98 \mathrm{a}$ \\
\hline Thiamine (spray) & 41.33a & $15.33 a$ & $56.55 a$ & 157.00ab & $90.00 \mathrm{~b}$ & $8.08 a$ & $1.11 \mathrm{a}$ & $13.78 a$ \\
\hline $\begin{array}{l}\text { A. brasilense + Thiamine } \\
\text { (spray) }\end{array}$ & $41.30 a$ & $15.33 a$ & $56.63 a$ & $128.25 c$ & $140.00 a$ & $7.45 a$ & $1.02 a$ & $13.73 a$ \\
\hline MSD & 3.15 & 3.97 & 6.90 & 27.06 & 37.00 & 2.93 & 0.40 & 2.03 \\
\hline CV\% & 3.90 & 12.82 & 6.17 & 9.45 & 18.38 & 20.09 & 19.20 & 7.07 \\
\hline
\end{tabular}

*Means followed for the same letter do not present statistical difference when submitted to the Tukey test with $5 \%$ of probability. Relative index of chlorophyll a (CA), b (CB) and Total (CT); Height of plants (HP); Shoot number (SN); Fresh matter (FM); Dry mass (DM); Dry mass index (DMI); Minimum significant difference (MSD) Coefficient of variance (CV).

For the relative contents of chlorophyll obtained at the time of first cut of millet plants, it was observed that the treatment with isolated inoculation of $A$. brasilense stood out, but there was a significant difference only on the treatment with thiamine alone application via seed treatment. However, there was no significant residual effect of the inoculation on the second cut.

Having a direct relation with the internal contents of pigments and leaf nitrogen in grass species (ROCHA et al., 2010; SILVA et al, 2014), the increase of chlorophyll relative levels is related to the fixation capacity of atmospheric nitrogen by bacteria of the genus Azospirillum (BATTISTUS et al., 2014), that can culminates in a bigger protein content.

At the time of the second cut of the millet plants, a slight superiority of the treatment composed by the application of thiamine on seed was observed for the height of the plants, with a significant difference only for the isolated inoculation treatments of $A$. brasilense and combined foliar application of thiamine (Table 1).

It was also observed that the lower height for the combined treatment with 
inoculation with $A$. brasilense and foliar application of thiamine showed an inverse relation to the number of shoots and this treatment was superior in relation to this characteristic, with an increase of $51.0 \%$ in the number of shoots per $\mathrm{m}^{2}$ in relation to the control treatment. However, there was no significant difference in relation to the treatment composed by inoculation with $A$. brasilense and thiamin on seed. This result can be a consequence of a negative interaction between the bacteria and the vitamins, as it was observed for sweet maize (VENDRUSCOLO et al., 2018), since the variation on thiamine content can be a signal against stress effect (GOYER, 2010).

However, the positive results, increases on vegetative and reproductive characteristics, are probably due to the promotion capacity of the production of endogenous hormones in plant tissues, observed for both bacteria and vitamin (OERTLI, 1987; EL-LATTIEF, 2016). In addition, the joint use of these products may have favored the root development by the action of the bacteria (COSTA et al., 2015) and the accumulation of energy reserves in the root tissues during the first cycle due to the improvement of photosynthetic capacity (KAYA et al. 2014), favoring the emission of larger shoots (FOLONI et al., 2008).

In studies conducted to evaluate the regrowth of grass species, it is observed that the use of nitrogen fertilization positively affects the emission of new shoots (MORAIS et al., 2006; FOLONI et al., 2008) and the fixation of the atmospheric nitrogen, carried out by $A$. brasilense, can exert such influence, since the bacterial fixing capacity is enough to increase the development of several types of grasses (HUNGRIA, 2011). In this sense, it is observed that the increase in nitrogen availability tends to reduce the relationship between auxins and cytokines (WILLIAMSON et al., 2012). The increased participation of cytokines in this relationship culminates in a greater development of shoots, since auxin suppression results in a decrease in bud dormancy.

Based on the results obtained and on the effects observed with the thiamine application alone or with the inoculation with $A$. brasilense, it is possible to infer that there is potential for the application of these techniques in obtaining higher pasture performance. However, the realization of new studies is essential to determine the dosages and methods of application of the treatments.

\section{Conclusions}

The inoculation with $A$. brasilense increases the relative chlorophyll content of millet during the first cycle.

The joint use of inoculation with $A$. brasilense and application of thiamine, via seed treatment or via foliar sprays can be used as strategy for improvement of the shoot number of the plants after regrowth.

\section{References}

AHN, P.; KIM, S.; LEE. Y. Vitamin B1 functions as an activator of plant disease resistance. Plant Physiology, v.13, p.1505-1515, 2005. https://doi.org/10.1104/pp.104.058693

BATTISTUS, A.G.; HACHMANN, T.L.; MIORANZA, T.M.; MULLER, M.A.; MADALOSSO, T.; FAVORITO, P.A.; GUIMARAES, V.F.; KLEIN, J.; KESTRING, D.; INAGAKI, A.M.; BULEGON, L.G. Synergistic action of Azospirillum brasilense combined with thiamethoxam on the physiological quality of maize seedlings. African Journal of Biotechnology, v.13, n.49, 2014. https://doi.org/10.5897/AJB2014.14059

BOUBAKRI, H.; WAHAB, M.A.; CHONG, J.; BERTSCH, C.; MLIKI, A.; SOUSTRE-GACOUGNOLLE, I. Thiamine induced resistance to Plasmopara viticola in grapevine and elicited host-defense responses, including HR like-cell death. Plant Physiology and Biochemistry, Amsterdam, v.57, n.1, p.120-133, 2012. https://doi.org/10.1016/i.plaphy.2012.05.016

CARDOSO, M.R.D.; MARCUZZO, F.F.N.; BARROS, J.R. Classificação climática de Köppen-Geiger para o estado de Goiás e o Distrito Federal. Acta Geográfica, v.8, n.16, p.40-55, 2015.

COSTA, R.R.G.F.; QUIRINO, G.D.S.F.; NAVES, D.C.D.F.; SANTOS, C.B.; ROCHA, A.F.D.S. Efficiency of inoculant with Azospirillum brasilense on the growth and yield of second-harvest maize1. Pesquisa Agropecuária Tropical, Goiânia, v.45, n.3, p.304-311, 2015. https://doi.org/10.1590/1983-

40632015v4534593

DAN, H.A.; BARROSO, A.L.L.; PROCOPIO, S.O.; DAN, L.G.M.; FINOTTI, T.R.R.; ASSIS, R.L. Seletividade do Atrazine à cultura do milheto (Pennissetum glaucum). Planta Daninha, v.28, 
p.1117-1124,

2010.

https://doi.org/10.1590/S0100-

$\underline{83582010000500019}$

DIAS-FILHO, M.B. Uso de pastagens para a produção de bovinos de corte no Brasil: passado, presente e futuro. Belém: Embrapa Amazônia Oriental, 2016. p. 42.

DONAGEMMA, G.K.; CAMPOS, V.D.B.; CALDERANO, S.B.; TEIXEIRA, W.G.; VIANA, J.H.M. 2011. Manual de métodos de análise de solo. 2. ed. Rio de Janeiro: Embrapa Solos, 2011. 230p.

EL-LATTIEF, E.A.A. Use of Azospirillum and Azobacter bacteria as biofertilizers in cereal crops: a review. International Journal of Research in Engineering and Applied Sciences, v.6, n. 7, p.36-44, 2016.

FAO. Livestock and animal production. 2017a. Disponível em: http://www.fao.org/ag/againfo/themes/en/anim al_production.html. Acesso em: 14 feb. 2019.

FAO. Livestock primary. 2017b. Disponível em: http://www.fao.org/faostat/en/\#data/QL. Acesso em: 14 feb. 2019.

FERREIRA, D.F. Sisvar: a guide for its bootstrap procedures in multiple comparisons. Ciência e Agrotecnologia, v.38, n.2, p.109-112, 2014. https://doi.org/10.1590/S1413-

$\underline{70542014000200001}$

FOLONI, J.S.; TIRITAN, C.S.; CALONEGO, J.C.; DUNDES, L.R. Rebrota de soqueiras de sorgo em função da altura de corte e da adubação nitrogenada. Revista Ceres, v. 55, n. 2, 2008.

GUIMARÃES, S.L.; BONFIM-SILVA, S.; KROTH, B.; MOREIRA, C.; MOREIRA, D. Crescimento e desenvolvimento inicial de Brachiaria decumbens inoculada com Azospirillum spp. Enciclopédia Biosfera, Goiânia, v.7, n.13, p.286-295, 2011.

GÖRGEN, A.V.; CABRAL FILHO, S.L.S.; LEITE, G.G.; SPEHAR, C.R.; DIOGO, J.M.D.S.; FERREIRA, D.B. Productivity and forage quality of buckwheat ("Fagopyrum esculentum" Moench) and pearl millet ("Pennisetum glaucum"(L.) R. BR). Revista Brasileira de Saúde e Produção Animal, v.17, n.4, p.599-607, 2016. https://doi.org/10.1590/s1519$\underline{99402016000400004}$
GOYER, A. Thiamine in plants: aspects of its metabolism and functions. Phytochemistry v. 71, n. 14-15, p. 1615-1624, 2010. https://doi.org/10.1016/i.phytochem.2010.06.02 2

HENDAWY, S.F.; EZZ EL-DIN, A.A. Growth and yield of Foeniculum vulgar var. Azoricum as influensed by some vitamins and amino acids. Ozean Journal Applied Science, v.3, p.113-123, 2010.

HUNGRIA, M. Inoculação com Azospirillum brasiliense: inovação em rendimento a baixo custo. Londrina: Embrapa Soja. 2011. 38p.

IBGE. Censo agro 2017. Disponível em: https://censoagro2017.ibge.gov.br/templates/ce nso agro/resultadosagro/pecuaria.html. Acesso em: 14 feb. 2019.

KAYA, C.; ASHRAF, M.; SONMEZ, O.; TUNA, A.L.; POLAT, T.; AYDEMIR, S. Exogenous application of thiamin promotes growth and antioxidative defense system at initial phases of development in salt-stressed plants of two maize cultivars differing in salinity tolerance. Acta Physiologiae Plantarum, v.37, p.1741-1753, 2015. https://doi.org/10.1007/s11738-014-1741-3

KISSMANN, K.G. Plantas infestantes e nocivas. São Paulo: BASF, 1991, v. 1, 608p.

LONGHINI, V.Z.; SOUZA, W.C.R.; ANDREOTTI, M.; SOARES, N.A.; COSTA, N.R. Inoculation of diazotrophic bacteria and nitrogen fertilization in topdressing in irrigated corn. Revista Caatinga, v.29, p.338-347, 2016. https://doi.org/10.1590/1983-

21252016v29n210rc

MOHSEN, A.A.; EBRAHIM, M.K.H.; GHORABA, W.F.S. Effect of salinity stress on Vicia faba productivity with respect to ascorbic acid treatment. Iranian Journal of Plant Physiology, v.3, n.3, p.725-736, 2013.

MORAIS, R.V.D.U.; FONSECA, D.M.D.; NASCIMENTO JÚNIOR, D.D.; RIBEIRO JUNIOR, J. I.; FAGUNDES, J.L.U.; MOREIRA, L.D.M.U.; MISTURA, C.; MARTUSCELLO, J.A.U. Demografia de perfilhos basilares em pastagem de Brachiaria decumbens adubada com nitrogênio. Revista Brasileira de 
Zootecnia, v.35, n.2, p.380-388, 2006. https://doi.org/10.1590/S1516$\underline{35982006000200007}$

OERTLI, J.J. Exogenous application of vitamins as regulators for growth and development of plants - a review. Zeitschrift für Pflanzenernährung und Bodenkunde, v.150, n.6, p.375-391, 1987. https://doi.org/10.1002/jpln.19871500604

PEREIRA, M.G., SANTOS, C.E.; DE FREITAS, A.D.; STAMFORD, N.P.; DA ROCHA, G.S.; BARBOSA, A. $\mathrm{T}$. Interactions between arbuscular mycorrhizal fungi Rhizobium and actinomycetes in the rhizosphere of soybean. Revista Brasileira de Engenharia Agrícola e Ambiental, v.17, n.12, p.1249-1256, 2013. https://doi.org/10.1590/S1415$\underline{43662013001200001}$

ROCHA, R.N.C.; GALVÃO, J.C.C.; TEIXEIRA, P.C.; MIRANDA, G.V.; AGNES, E.L.; PEREIRA, P.R.G.; LEITE, U.T. Relação do índice SPAD, determinado pelo clorofilômetro, com teor de nitrogênio na folha e rendimento de grãos em três genótipos de milho. Revista Brasileira de Milho e Sorgo, v.4, n.2, p.161-171, 2010. https://doi.org/10.18512/1980-

6477/rbms.v4n2p161-171

SANTOS H. G.; JACOMINE, P. K. T.; ANJOS, L.H.C.; OLIVEIRA, V.A.; LUMBREIRAS, J.F.; COELHO, M.R.; ALMEIDA, J.A.; CUNHA, T.J.F.; OLIVEIRA, E.J.B. Sistema brasileiro de classificação de solos. 3 . ed. Brasília: Embrapa, 2013. 353p.

SILVA, F.C.D.S. (Ed.). Manual de análises químicas de solos, plantas e fertilizantes. Rio de Janeiro: Embrapa Solos, 2009. 627p.

ROHRIG, B.; SCHNEIDER, E.P.; ZWIRTES, A.; SOBUCKI, L.; RAMOS, R.F.; SCHMITT, O.J. Nodulação, crescimento e desenvolvimento de feijão inoculado com diferentes estirpes de Rhizobium. Ciência \& Tecnologia Fatec-JB, v.8, n.esp., 2016.

SILVA, M.D.A.; SANTOS, C.M.D.; VITORINO, H.D.S.; RHEIN, A.F.D.L. Pigmentos fotossintéticos e índice SPAD como descritores de intensidade do estresse por deficiência hídrica em cana-deaçúcar. Bioscience Journal, v.30, n.1, p.173-181, 2014.
SOLTANI, Y.; SAFFARI, V.R.; MOUD, A.A.M. Response of growth, flowering and some biochemical constituents of Calendula officinalis L. to foliar application of salicylic acid, ascorbic acid and thiamine. Ethno-Pharmaceutical Products, Kerman, v.1, n.1, p.37-44, 2014.

VENDRUSCOLO, E.P.; OLIVEIRA, P.R.; SELEGUINI, A. Aplicação de niacina ou tiamina promovem incremento no desenvolvimento de mostarda. Cultura Agronômica, v.26, n.3, p.433-442, 2017. https://doi.org/10.32404/rean.v5i4.2766

VENDRUSCOLO, E.P.; SIQUEIRA, A.P.S.; FURTADO, J.P.M.; CAMPOS, L.F.C.; SELEGUINI, A. Development and quality of sweet maize inoculated with diazotrophic bacteria and treated thiamine. Journal of Neotropical Agriculture, v.5, n.4, p.45-51, 2018.

VOGEL, G.; MARTINKOSKI, L.; RUZICKI, M. Efeitos da utilização de Azospirillum brasilense em poáceas forrageiras: Importâncias e resultados. Agropecuária Científica no Semiárido, v.10, n.1, p.01-06, 2014.

WILLIAMSON, M.M.; WILSON, G.W.; HARTNETT, D.C. Controls on bud activation and tiller initiation in C3 and C4 tallgrass prairie grasses: the role of light and nitrogen. Botany, v.90, n.12, p.1221-1228, 2012. https://doi.org/10.1139/b2012-091 